B.C. SCHUTTE en I.P. SCHOLTZ. Ouer, $u$ kind! (in u skool). 'n Gids vir verloofdes, studente, ouers en onderwysers. Potchefstroom, Pro Rege, s.j., pp. 74. Prys R1,00.

Hierdie interessante boekie is uitgegee onder beskerming van die Koördinerende Komitee vir Christelike Onderwys. Dit handel oor aktuele vraagstukke aangaande die interne skoollewe, skooldienste en opvoedende onderwys en is 'n móét vir die:

* Christen-ouer wat erns maak met die opvoeding en onderwys van sy kind,

* Christen-onderwyser wat 'n bydrae wil lewer tot die Christelike opvoedingsideaal en

* Christen-jongmens wat van meet af aan die stene reg wil lê.

Die lees van Ouer, $u$ kind! is 'n verrykende ondervinding en hierdie werkie word met beslistheid aanbeveel.

S.S. Barnard

$\mathrm{PU}$ vir $\mathrm{CHO}$

**

BIBLIOGRAFIE OOR CALVINISME

Die vierdelige reeks Die inslag van die Calvinisme - 'n Bibliografie van Suid-Afrikaanse tydskrifartikels het pas in Reeks F van die PU vir CHO se Wetenskaplike bydraes verskyn. Dit beslaan die volgende:

Deel 1: Histories en prinsipieel (271 pp) @ R5,50

Deel 2: Godsdienstig en teologies (592 pp) @ R10,00

Deel 3: Wetenskaplik en opvoedkundig (289 pp) @ R 7,25

Deel 4: Maatskaplik en staatkundig (405 pp) @ R5,60

Navrae kan gerig word aan:

Die Universiteitsbibliotekaris

Ferdinand Postma-Biblioteek

PU vir CHO

Potchefstroom

2520

** 
VAN DER TAS, G. 1978. De lichamelijk opvoeding in het licht der Schrift. Oosterbaan, Goes.

Die tema van hierdie werk is aktueel, vandag miskien meer as 'n paar dekades gelede, danksy die geweldige ontwikkeling wat die Liggaamlike Opvoedkunde ondergaan het. Die vraag na die $\sin /$ betekenis/waarom van dinge, is ' $n$ vraag wat die moderne mens graag wil beantwoord hê.

Die skrywer dek 'n wye veld met sy tema maar slaag daarin om telkens elke aspek van die Liggaamlike Opvoeding onder die heldere lig van die Skrif te plaas.

Die gebruik van die term ,Liggaamlike Opvoeding" dui aan dat dit in die publikasie oor die praktiese implementering van die wetenskap „Liggaamlike Opvoedkunde" sal handel. Dit is skade dat die skrywer die gebruik van die term nie duidelik gestel het nie. Daardeur sou die gedagtes beslis nog meer op die punt af kon gewees het.

Die skrywer beweer op p. 13: „Geen ware opvoeding is mogelijk en denkbaar zonder de richtende en steunende kracht van een wereld-, levens- en mensbeskouwing". Dit wys reeds op die voorwetenskaplike uitgangspunt wat die skrywer sal handhaaf.

Onder die opskrif „De bestemming van deze studie” stel die skrywer dat dit gaan om 'n „,Calvinistische en de christelijk-wetenschapplijke grondvesting van de lichamelijke opvoeding en opvoedkunde". Die skrywer gaan dan voort om die mens in sy analogie en verhouding tot God te skets en telkens word verwys na die liggaam (versorging en verantwoordelikheid). Hierdeur word die liggaam tot 'n besittingsubstansie van die mens - wat dus iets anders moet wees - verhef.

Die geskiedenis van die Liggaamlike Opvoeding is die tema van die volgende hoofstuk. Met sesmyltreë gaan die skrywer deur die geskiedenis en trek raak 'n lyn onder uitstaande gebeure en persone. In die sketsing van die moderne beskouing stel hy onder andere die volgende (p. 35): „Deze psychologie (verwys na sy vorige $\sin$ ) steunt de eisen voor ruimschootse gelegenheid tot lichamelijke oefenen. In haar verschillende verschijningsvormen doet deze 'totaliteits-psychologie' beseffen dat de opvoeding zich niet tot een paar menselijke afdelingen en bepaalde eigenschappen, tot de verstandelijke en het morele kan beperken, maar dat via het lichamelijke ook de geest van de mens gevormd, verrijkt en ontwikkeld wordt".

Die skrywer skets enkele mensbeskouings raak met die duidelike konsekwensies van sodanige beskouings vir die Liggaamlike Opvoeding.

Vanuit die Christelike antropologie en die mens in sy geroepenheid word die plek en die noodsaaklikheid van die Liggaamlike Opvoeding geskets as- 
ook die inhoud wat aan die vak gegee behoort te word.

Dwarsdeur die lees van die werk kom twee uitstaande aspekte na vore te wete eerstens die besondere betekenis wat die Skrifgefundeerde benadering vir die Liggaamlike Opvoeding het en tweedens die onvermoë van die skrywer om heeltemal met 'n dichotomiese beskouing oor die mens en sy optrede te breek.

Die literatuurlys bevestig die besef dat die skrywer die veld vanuit verskillende hoeke benader het. Ek is daarvan - rtuig dat elke Christen wat die Liggaamlike Opvoedkunde as studieveld kies, ryklik kan put uit hierdie publikasie.

\section{W.J. Putter}

$\mathrm{PU}$ vir $\mathrm{CHO}$ 